\title{
Features of Expert Activities in the Construction Sector of the Economy: Case of Kazakhstan
}

\author{
Anna Shevyakova ${ }^{1}$, Elena Petrenko ${ }^{2}$, Malika Arystan ${ }^{3}$ \\ And Gaukhar Koshebayeva ${ }^{4}$ \\ ${ }^{1}$ LLP "Rational solutions", Karaganda, The Republic of Kazakhstan, \\ PI Academy "Bolashaq", Karaganda, The Republic of Kazakhstan \\ ${ }^{2}$ Plekhanov Russian University of Economic, Moscow, Russian Federation \\ ${ }^{3}$ Karaganda Economic University, Karaganda, The Republic of Kazakhstan \\ ${ }^{4}$ Karaganda State Technical University, Karaganda, The Republic of Kazakhstan
}

Correspondence should be addressed to: Anna Shevyakova; shevyakova.anna@gmail.com

Received date: 2 April 2019; Accepted date:9 July 2019 ; Published date: 16 September 2019

Academic Editor: Viktoria Anatolievna Degtereva

Copyright (C) 2019. Anna Shevyakova, Elena Petrenko, Malika Arystan And Gaukhar Koshebayeva. Distributed under Creative Commons CC-BY 4.0

\begin{abstract}
The article deals with the functioning of special institutions in the economy of Kazakhstan, as a country with active state participation on the example of the system of state examination of projects and the monopolistic subject of the Republican state enterprise on the right of economic management "State independent departmental examination of projects" (hereinafter RSE "Gosexpertiza"). Construction is recognized as one of the priorities of the Development Strategy of Kazakhstan until 2050 and is one of the most important tasks of a national nature. The quality of the design depends decisively on the efficiency of funds and resources invested in construction, the investment activity of customers, the construction and operational reliability of facilities, their architectural expressiveness, the solution of social, environmental and other problems of society and the state. For entry into the international economic space, it is necessary to introduce international quality standards for facilities under construction.
\end{abstract}

Keywords: Kazakhstan, economy, institutional changes, construction sector, state expertise of projects, competitiveness

JEL Classification: L43, L74, L44

Cite this Article as: Anna Shevyakova, Elena Petrenko, Malika Arystan And Gaukhar Koshebayeva (2019), "Features of Expert Activities in the Construction Sector of the Economy: Case of Kazakhstan ", Journal of Economics Studies and Research, Vol. 2019 (2019), Article ID 958134, DOI: $10.5171 / 2019.958134$ 


\section{Introduction}

The efficiency of the business support infrastructure depends on the degree of development of the institutional environment, its quality and development (e.g. Tvaronavičienè, 2018; Nikitina et al., 2018). The high level of development of the institutional environment contributes to increasing the effectiveness of state and non-state support in a market economy, its targeting, reducing the time from filing an application for support to its implementation, reducing transaction costs and increasing confidence in public authority (Mavlyanova et al., 2015; Kapitonov et al. 2017).

The purpose of the study is to describe a special institute in the construction sector of the economy of Kazakhstan, as a country with active state participation in the economy, and also to suggest ways of reforming expert activities in the construction sector. Methodology economic-statistical methods of research, comparison, dialectic method of cognition of the phenomenon from the general to the particular are used.

The relevance of the article lies in the analysis of the main indicators of the socioeconomic development of Kazakhstan, including the construction sector, a comparative analysis of institutional support tools for entrepreneurship and peculiarities of expert activities in different countries, identifying possible negative effects of monopolizing the expertise of construction projects on economic growth in Kazakhstan. The research results confirm the need for reforming expert activities to change the current negative situation.

World experience shows that the role of the state in the development of the economy is not limited to policymaking, maintaining macroeconomic stability and regulating the activities of economic entities. It must also assume strategic and coordinating functions in economic processes. The development of entrepreneurship in any state is one of the most actively discussed problems of our time. The success of the development of national entrepreneurship, which is able to ensure sustainable economic development, essentially, depends on the stability of the state. Currently, there are many unsolved problems: both in theory and in the practice of entrepreneurial activity, which leads to its lack of effectiveness, tangible losses for state, economy and society.

The issues of economic development have taken into account the regional peculiarities, the peculiarities of formation of associations of countries and the formation of economic; and political associations have been repeatedly considered in the writings of economists and sociologists (Anson et al., 2004; Boronenko \& Lavrinenko, 2015; Clarke, 2018; Ignatavičius et al., 2015; Tvaronavičienė, 2018; Shevyakova et al., 2016).

The institutional structure of society includes a system of interrelated institutions that promote the reproduction of socio-economic relations. Institutional foundations are formed under the influence of historical, socio-cultural traditions and have in each country its own characteristics and deep roots, form the order of relationships in society. Entrepreneurship has always been claimed by society as a special creative function, which is not private, but institutional. The development of institutional theory was largely due to the desire to successfully develop a business. In his works, Douglas North (North, 1997), a leading institutional scientist, asked, perhaps, the most pressing question for all: "Why are some countries rich and others poor?". Having lived two decades in a market society, we can ask this question again.

According to D. North, "institutions create the basic structures through which people throughout history have achieved order and thus reduced their uncertainty .... they determine the cost of operations and transformations ... profitability and soundness of economic activity". Why does business, the nature of which is based on 
personal initiative, activity and dedication, have additional incentives and special structures?

In every society, in every market, there is a certain number of businessmen postponing their entrepreneurial initiative due to the presence of many obstacles and restrictions in the market. They do not fully utilize their resources and do not invest either because of high transaction costs, some of which arise due to institutional constraints. Delays in obtaining licenses, necessary permits and approvals, acquiring assets and obtaining bank loans lead to the suppression of investment. Corruption increases the costs of doing business, unreasonable tariffs inflate prices and interfere with sales, and administrative barriers can stop the most promising project.

The economic growth of national economies and the world economy is ensured through "institutional building", which is carried out gradually, coordinated in a wide range of areas so that the whole system can function and develop even if there are some gaps. At the global level, there is still ongoing discussion about the effectiveness and degree of sophistication of modern institutions. The World Bank report (2012) notes that "the development economy has not yet come to a wellformulated institutional theory suitable for a world full of heterogeneous economies with a colorful history, at various stages of development".

The Bank's survey showed that land privatization did not affect the inflow of investments and the availability of credit to African farmers. Latin American countries actively pursued political reforms and created institutions in the 1980s and 1990s, but this did not lead to the expected growth. The countries of East Asia, at the same time, achieved significant economic growth, while their institutions were weak and progressed slowly.

Support institutions, with the exception of the simplest, cannot be used to achieve a specific short-term goal. The formation of institutions is not just following the rules, since there are no uniform models. The only expedient approach is the gradual and consistent construction of institutions at the grassroots level through local efforts. Each state must find its own model, direct borrowing is impossible and dangerous. According to Joseph Y. Stiglits (World Bank Report 2012), "under the leadership of Wolfensohn, the Bank moved from projects to real political decisions and from political decisions to institutions".

J. Y. Stiglitz, on the basis of his own research, argues that "the naive view that non-market institutions helped correct market failures was erroneous or, at least, needed to rethink many of the nuances of non-market institutions could actually be destructive...". In the figurative expression of Shahid Yusuf, "the line leading from institutions to the results of activity is not at all direct".

\begin{abstract}
International experience in the development of private business demonstrates the presence of a large number of different support tools. Such qualitative diversity confirms the statement that the establishment of support institutions should take place at the local level, taking into account regional specificities.
\end{abstract}

Institutional support for entrepreneurship is traditionally strong in the Nordic countries. In Finland, seven institutional entities have been created and their activities are related to the provision of a wide range of public services to small and medium-sized businesses. Despite the relatively small geographical size of the country, business support institutions in Finland have a developed network of branches, ensuring accessibility to services for entrepreneurs of any region.

An important institutional factor is the optimal state of the permit system. In Singapore, there are only 8 types of licensing, in the European Union countries, an average of 10-12 types of activities are subject to licensing, in India and Hungary, 5 types of activitie are subject to licensing s (Finkel, 2015; Gruneberg, 2018). The licensing system of Kazakhstan and the 
countries of the Eurasian Economic Union is complex, cumbersome and inconsistent procedures and standards, which creates obstacles to the development of a single business community.
Table 1 presents the institutional support tools for entrepreneurship used in various countries. In addition, almost all states that have developed and successful domestic entrepreneurship possess legislative support for the protection of intellectual property and copyright.

Table 1: Institutional support tools for entrepreneurship

\begin{tabular}{|c|c|}
\hline Support Tools & $\begin{array}{l}\text { Countries of } \\
\text { application }\end{array}$ \\
\hline $\begin{array}{l}\text { State programs of financial and technical support for business } \\
\text { entities working on the request of the state }\end{array}$ & $\begin{array}{l}\text { USA, Japan, UK, India, } \\
\text { China }\end{array}$ \\
\hline $\begin{array}{l}\text { Direct financing (subsidies, loans), up to } 50 \% \text { of the cost of creating } \\
\text { new products and technologies }\end{array}$ & France, USA and others \\
\hline Granting loans, including without interest & Sweden \\
\hline Grants for $50 \%$ of the costs of innovation & Germany \\
\hline $\begin{array}{l}\text { Reducing government fees for individual inventors and providing } \\
\text { them with tax breaks }\end{array}$ & $\begin{array}{l}\text { Austria, Germany, USA, } \\
\text { Japan and others }\end{array}$ \\
\hline $\begin{array}{l}\text { Creating a special infrastructure to support entrepreneurship and } \\
\text { economic insurance }\end{array}$ & Japan \\
\hline $\begin{array}{l}\text { Free services of patent attorneys at the request of individual } \\
\text { inventors, exemption from fees }\end{array}$ & $\begin{array}{l}\text { Netherlands, Germany, } \\
\text { Japan, India }\end{array}$ \\
\hline $\begin{array}{l}\text { Tax relief for enterprises operating in the innovation sphere, incl. } \\
\text { exemption from taxation of R\&D costs, preferential taxation of } \\
\text { universities and research institutes }\end{array}$ & $\begin{array}{l}\text { USA, UK, India, China, } \\
\text { Japan }\end{array}$ \\
\hline Government programs for risk reduction and risk reimbursement & USA, Japan \\
\hline $\begin{array}{l}\text { Creation of large state organizations (corporations, agencies) } \\
\text { providing comprehensive information, scientific and technical, } \\
\text { financial and production support of entrepreneurship }\end{array}$ & $\begin{array}{l}\text { USA, India, China, Japan } \\
\text { and others }\end{array}$ \\
\hline
\end{tabular}

Source: composed by the authors

\section{Special institute in the construction sector: case of Kazakhstan}

The unique model of business development is implemented by the Republic of Kazakhstan. The infrastructure to support entrepreneurship is a complex of organizations that provide favorable conditions for the creation, functioning and development of private entrepreneurship. In the Republic of Kazakhstan, such organizations include: state organizations and organizations established on the initiative of the state, non-governmental and commercial organizations.

Today in the republic, business development services are provided by: Engineering and Technology Transfer Center, Export Development and
Promotion Corporation "Kaznex", "Damu" Entrepreneurship Development Fund, National Innovation Background, Development Bank of Kazakhstan. Technoparks, business incubators, industrial zones operate in the Republic.

In 2013, the largest non-governmental organization for the support of small and medium-sized businesses, the National Chamber of Entrepreneurs (NCE) of the Republic of Kazakhstan Atameken, was established in the republic, which brought together all 1.7 million economic entities of the republic. The purpose of the creation of the National Chamber is the formation of an institutional framework for the growth and further development of entrepreneurship in the Republic of Kazakhstan. 
In the first year of operation, the NCE already conducted an examination of more than 5 thousand regulatory acts, has achieved the abolition of 54 licensing procedures and reduced the requirements of government agencies by $35 \%$ in order to conduct business audits. However, administrative barriers in the republic continue to be an obstacle to the development of entrepreneurship. Even after the cancellation of a part of the requirements in Kazakhstan, the 3418 requirement of the regulatory authorities continues to operate, most of which are related to activities in the construction sector of Kazakhstan (Business Climate, 2016).

The construction sector in Kazakhstan remains both one of the important sectors of the economy (the main indicators of the socio-economic development of Kazakhstan are shown in Table 2) and one of the most attractive areas of investment. The share of this sector accounts for up to $6 \%$ of Kazakhstan's GDP; in terms of employment, the construction sector provides about 700 thousand jobs.
In the period under review, demographic indicators had a general tendency of insignificant growth. The total population growth was $115 \%$, while the growth of the employed population was slower and amounted to $110.8 \%$. The economy of the republic is developing in conditions of limited human resources and with the restriction of external migration, all internal reserves are used. During the period under review, the unemployment rate fell from $6.6 \%$ to $4.8 \%$, and the retirement age in the republic was significantly increased. Labor productivity remains low, the growth of gross domestic product per capita production method over the decade was only 109.6\% (Figure 1).

The low efficiency of the labor market is also expressed in the decrease in incomes of the population. The average monthly nominal wage per employee fell by $7 \%$, and the average per capita nominal cash income fell by $3 \%$. For a period of 11 years, the national currency depreciated against the US dollar almost three times and the real level of decline in the standard of living and the depreciation of nominal income is several times more than official statistics. 
Table 2: The main socio-economic indicators of the development of Kazakhstan

\begin{tabular}{|c|c|c|c|c|c|c|c|c|c|c|c|}
\hline Indicators & 2008 & 2009 & 2010 & 2011 & 2012 & 2013 & 2014 & 2015 & 2016 & 2017 & 2018 \\
\hline \multicolumn{12}{|l|}{ Demographics } \\
\hline $\begin{array}{l}\text { Population at the end of the year, thousand } \\
\text { people }\end{array}$ & 15982,4 & 16203,3 & 16440,5 & 16673,9 & 16910,2 & 17160,9 & 17415,7 & 17669,9 & 17918,2 & 18157,3 & 18415,5 \\
\hline as a percentage of the previous year & 102,6 & 101,4 & 101,5 & 101,4 & 101,4 & 101,5 & 101,5 & 101,5 & 101,4 & 101,3 & 101,4 \\
\hline \multicolumn{12}{|l|}{ Standard of living } \\
\hline $\begin{array}{l}\text { Per capita nominal cash income of the } \\
\text { population, USD }\end{array}$ & 274,2 & 232,4 & 264,8 & 313,2 & 347,8 & 371,1 & 347,5 & 303,6 & 223,8 & 254,8 & 265,8 \\
\hline $\begin{array}{l}\text { Percentage of the population with incomes } \\
\text { below the subsistence minimum }\end{array}$ & 12,1 & 8,2 & 6,5 & 5,5 & 3,8 & 2,9 & 2,8 & 2,7 & 2,6 & 2,6 & 4,6 \\
\hline \multicolumn{12}{|l|}{ Labor market and wages } \\
\hline Employed population, thousand people & 7857,2 & 7903,4 & 8114,2 & 8301,6 & 8507,1 & 8570,6 & 8510,1 & 8433,3 & 8553,4 & 8585,2 & 8709,7 \\
\hline as a percentage of the previous year & 103,0 & 100,6 & 102,7 & 102,3 & 102,5 & 100,7 & 99,3 & 99,1 & 101,4 & 100,4 & \\
\hline Unemployment rate, percent & 6,6 & 6,6 & 5,8 & 5,4 & 5,3 & 5,2 & 5,0 & 5,1 & 5,0 & 4,9 & 4,8 \\
\hline $\begin{array}{l}\text { Average monthly nominal wage per employee, } \\
\text { USD }\end{array}$ & 505 & 456 & 527 & 614 & 679 & 717 & 675 & 568 & 418 & 463 & 470,7 \\
\hline \multicolumn{12}{|l|}{ National economy } \\
\hline $\begin{array}{l}\text { Gross domestic product by production method, } \\
\text { mln. USD }\end{array}$ & $\begin{array}{r}133 \\
440,7 \\
\end{array}$ & 115306,1 & $\begin{array}{r}148 \\
052,4 \\
\end{array}$ & $\begin{array}{r}192 \\
627,6 \\
\end{array}$ & $\begin{array}{r}208 \\
002,1 \\
\end{array}$ & $\begin{array}{r}236 \\
633,3 \\
\end{array}$ & $\begin{array}{r}221 \\
417,7 \\
\end{array}$ & $\begin{array}{r}184 \\
387,0 \\
\end{array}$ & $\begin{array}{r}137 \\
278,3 \\
\end{array}$ & $\begin{array}{r}162 \\
887,4 \\
\end{array}$ & $\begin{array}{r}170 \\
536,8 \\
\end{array}$ \\
\hline $\begin{array}{l}\text { Gross domestic product by per capita } \\
\text { production method, USD }\end{array}$ & 8513,5 & 7165,1 & 9071,0 & 11634,5 & 12387,4 & 13890,8 & 12806,7 & 10509,9 & 7714,8 & 9030,3 & 9330,9 \\
\hline Investments in fixed assets, mln. USD & 35003,1 & 31086,8 & 31581,5 & 34171,5 & 36705,5 & 39917,7 & 36784,9 & 31681,4 & 22686,2 & 26903,6 & 32288,5 \\
\hline $\begin{array}{l}\text { Index of physical volume of investment in fixed } \\
\text { assets }\end{array}$ & 114,8 & 102,9 & 97,0 & 102,9 & 104,1 & 106,9 & 104,2 & 103,7 & 102,0 & 105,8 & 117,2 \\
\hline \multicolumn{12}{|l|}{ Real Sector } \\
\hline $\begin{array}{l}\text { The volume of industrial production (goods, } \\
\text { services), mln. USD }\end{array}$ & 84744 & 61841 & 82155 & 108642 & 113016 & 117229 & 103405 & 67213 & 55608 & 69909 & 79998 \\
\hline $\begin{array}{l}\text { volume indices of industrial production, as a } \\
\text { percentage of the previous year }\end{array}$ & 102,6 & 102,7 & 109,6 & 103,8 & 100,7 & 102,5 & 100,3 & 98,4 & 98,9 & 107,3 & 104,1 \\
\hline $\begin{array}{l}\text { Volume of construction works (services), mln. } \\
\text { USD }\end{array}$ & 14859,8 & 12351,3 & 13192,8 & 14221,3 & 15202,2 & 16034,9 & 14884,6 & 13064,9 & 9521,9 & 10764,7 & 11148,3 \\
\hline $\begin{array}{l}\text { Index of physical volume of construction } \\
\text { works }\end{array}$ & 101,7 & 96,7 & 102,4 & 102,8 & 103,1 & 103,5 & 104,6 & 105,8 & 107,4 & 102,8 & 104,1 \\
\hline
\end{tabular}




\begin{tabular}{|c|c|c|c|c|c|c|c|c|c|c|c|}
\hline $\begin{array}{l}\text { The total area of commissioned residential } \\
\text { buildings, thousand sq. M. of total area }\end{array}$ & 6848 & 6403 & 6409 & 6531 & 6742 & 6844 & 7516 & 8940 & 10513 & 11168 & 12521 \\
\hline $\begin{array}{l}\text { Index of physical volume of the total area of } \\
\text { residential buildings commissioned }\end{array}$ & 102,5 & 93,5 & 100,1 & 101,9 & 103,2 & 101,5 & 109,8 & 118,9 & 117,6 & 106,2 & 112,1 \\
\hline \multicolumn{12}{|l|}{ Financial system } \\
\hline $\begin{array}{l}\text { Deficiency (surplus) of the state budget, mln. } \\
\text { USD }\end{array}$ & $-2770,07$ & $-3340,29$ & $-3578,31$ & $-3878,18$ & $-5970,82$ & $-4607,43$ & $-6064,35$ & $-4129,82$ & $-2156,06$ & $-4464,17$ & $-2416,73$ \\
\hline $\begin{array}{l}\text { The average annual exchange rate of USD, } \\
\text { tenge }\end{array}$ & 120,30 & 147,50 & 147,35 & 146,62 & 149,11 & 152,13 & 179,19 & 221,73 & 342,16 & 326,00 & 344,71 \\
\hline
\end{tabular}

Source: composed by the authors according to the Statistics Committee of the Republic of Kazakhstan 


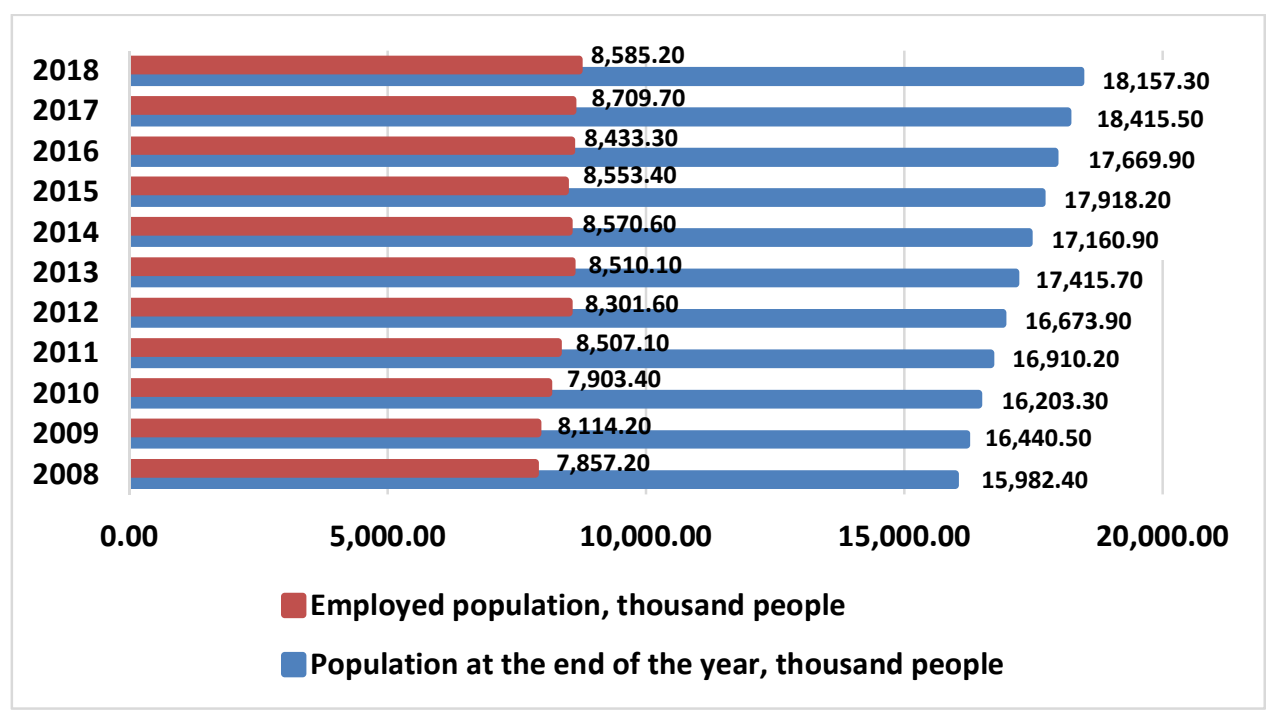

Fig.1: Dynamics of the number and employment of the population of Kazakhstan

Source: composed by the authors according to the Statistics Committee of the Republic of Kazakhstan

Figure 2 shows that the decline in unemployment does not correlate with the proportion of people living below the "poverty line". Until last year, the share of the population with incomes below the subsistence minimum consistently declined, but in 2018, there was a sharp increase (from $2.6 \%$ to $4.6 \%$ ) not accompanied by an increase in unemployment. Under the influence of external negative factors, there is a decrease in the general indicators of the efficiency of the economy and quality of life, but state policy supports official indicators and tries to restrain negative trends. As a result, many processes in Kazakhstan's economy are latent.

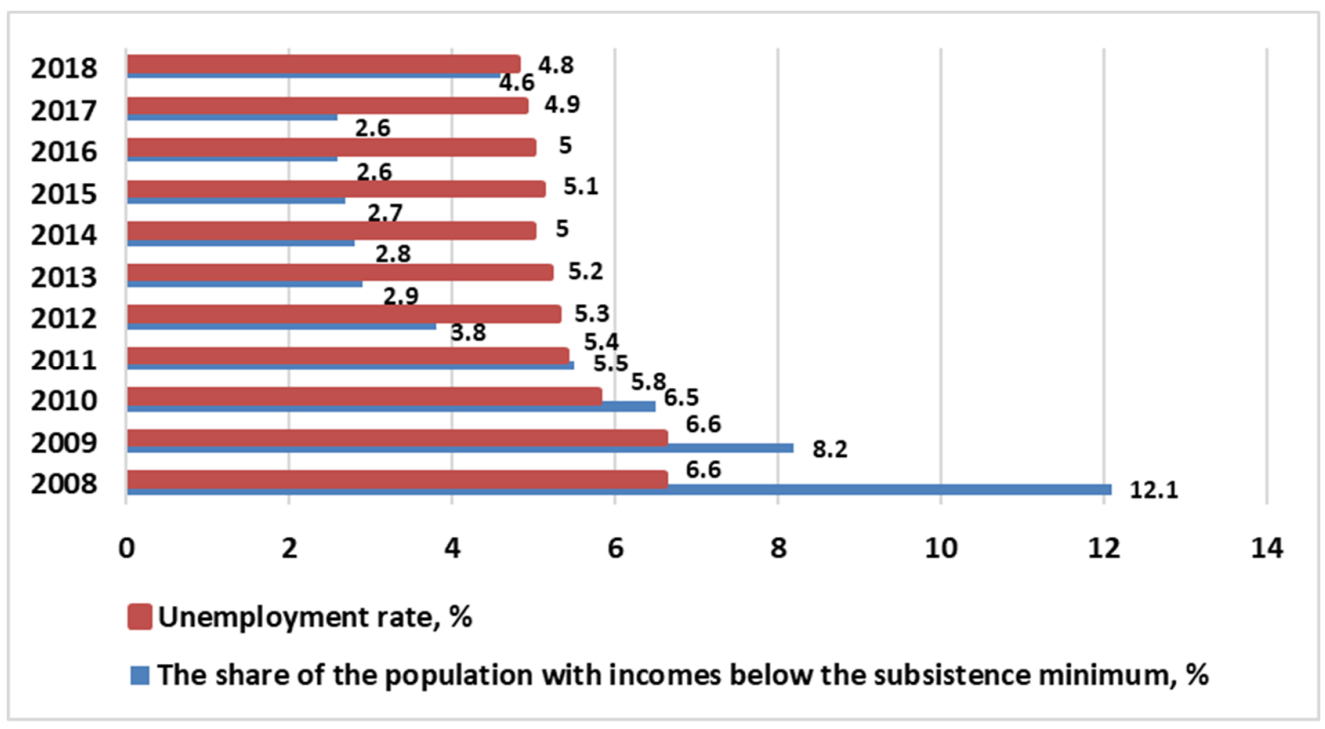

Fig.2: Dynamics of the standard of living of the population in Kazakhstan

Source: composed by the authors according to the Statistics Committee of the Republic of Kazakhstan

Anna Shevyakova, Elena Petrenko, Malika Arystan And Gaukhar Koshebayeva (2019), Journal of Economics Studies and Research, DOI:10.5171/2019.958134 
The government of Kazakhstan is, currently, actively involved in financing the construction of life-supporting infrastructure. The development of the state economy, the improvement of the material situation of the population led to the intensive development of construction in the country (Figure 3).

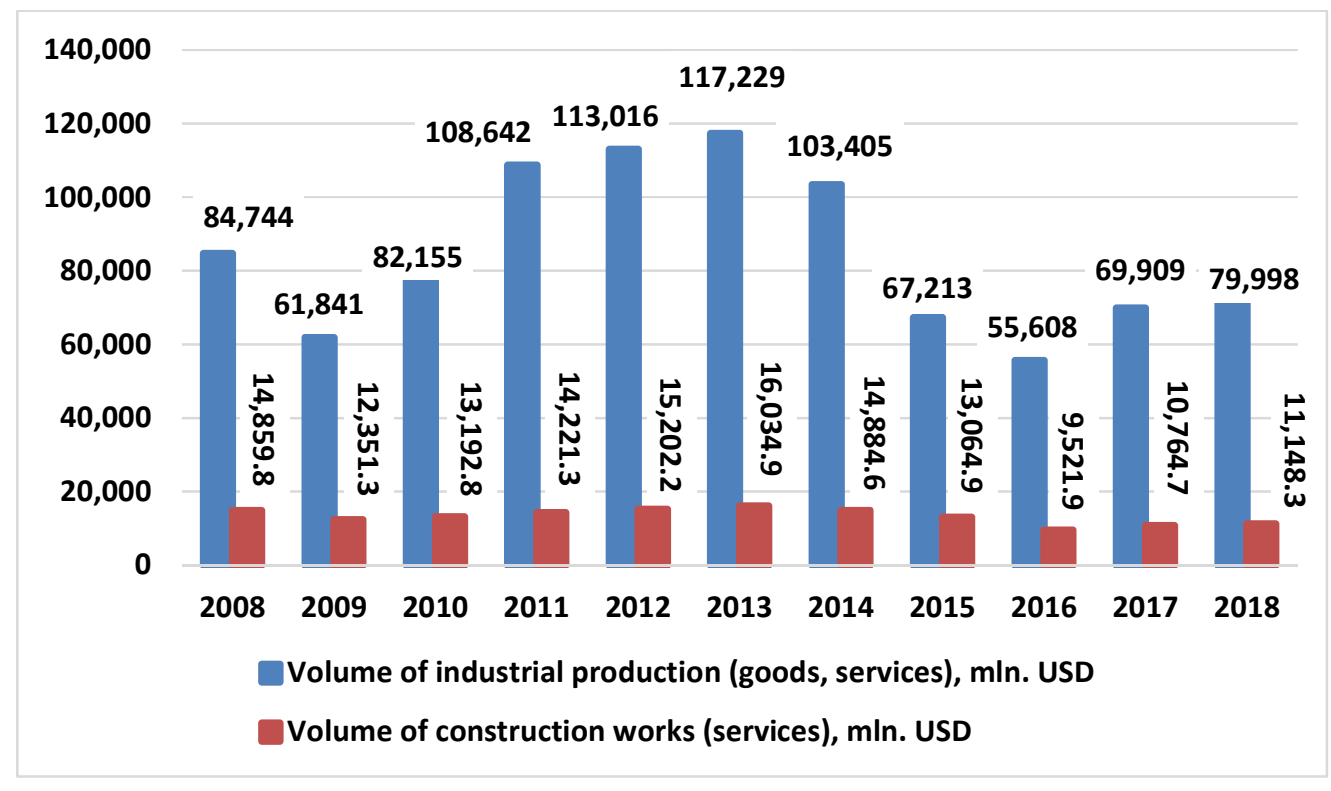

Fig.3: Volume dynamics of industrial production and construction works (services) in Kazakhstan

Source: composed by the authors according to the Statistics Committee of the Republic of Kazakhstan

During the period under review, the volume of industrial production (goods, services) is not stable, especially, the last 4 years, which is explained by low oil prices on the world market and the devaluation of the tenge in Kazakhstan. In 2018, the volume of industrial production (goods, services) was 4,746 million dollars below the 2008 level and is 94.3\%. In August 2015, a floating exchange rate of the national currency was introduced. And in general, over the past 11 years, the tenge weakened against the US dollar by $204 \%$ from 120.3 tenge to 344.71 in 2018 , i.e. almost 3 times, and over the past 3 years, 1.55 times (since the moment of the shock devaluation). The volume of completed construction work (services) remains fairly stable, but even during the period 20162018, the national currency depreciated and the budget revenues decreased due to a decrease in oil revenues. The average level of construction work (services) for 11 years amounted to $13204.2 \mathrm{mln}$. USD.

Construction is recognized as one of the priorities of the Development Strategy of Kazakhstan until 2050 and is one of the most important tasks of a national nature. The quality of the design depends decisively on the efficiency of funds and resources invested in construction, the investment activity of customers, the construction and operational reliability of facilities, their architectural expressiveness, the solution of social, environmental and other problems of society and the state. For complex objects, not only construction, but also design can be carried out over several years. 
Expert organizations in construction analyze and evaluate the effectiveness and quality of the substantiation of investments, programs, projects, architectural and construction, design and research projects relating to the construction of new ones, as well as modernization, technical re-equipment, expansion and constructions. By clarifying the rationale for investment, improving planning, design and engineering solutions, experts reduce the estimated cost of construction and resource consumption by an average of $10-15 \%$.

Examination of projects (pre-project and design estimates) intended for construction is of a paramount importance in ensuring the safety of future use of these facilities, affecting the quality of life of the country's population, ensuring their rights to a safe environment and habitat. Expert organizations act as a kind of barrier, demanding to bring the project into line with the norms of the law, thus, observing public and state interests.

The quality of design in Kazakhstan is given very serious attention, because the state in Kazakhstan is one of the main Customers of construction projects. Of the implemented construction projects in the Republic of Kazakhstan in 2017, more than $61.3 \%$ are financed by public investment, $17.4 \%$ by public investment and $21.3 \%$ by private investment. The state is an active participant in a market economy in Kazakhstan.

In order to create a full-fledged habitat and human life, sustainable development of human settlements and inter-settlement areas in the Republic of Kazakhstan, a legal framework has been established, the purpose of which is to regulate relations arising between government bodies; individuals and legal entities in the process of implementing architectural, townplanning and construction activities, The Law of the Republic of Kazakhstan was adopted on July 16, 2001 No. 242-II "On Architectural, Urban Planning and Construction Activity in the Republic of Kazakhstan", which is being constantly improved in order to improve the quality of projects as a result of expert examinations conducted on them. For the same purposes, the Regulation of the Government of the Republic of Kazakhstan dated January 25, 2012 No. 165 approved the Rules of certification of experts performing expert work and engineering services in the field of architectural, urban planning and construction activities.

Activities for the public examination of projects (pre-project and design estimates) now belong to the state monopoly and were carried out by republican state enterprise on the right of a business established by the decision of the Government of the Republic of Kazakhstan (RSE "Gosexpertiza"). RSE "Gosexpertiza" is a special and specialized state institution in the market economy of Kazakhstan, which holds a monopoly position.

The Republican unified state system of private departmental examination of projects was formed by the Resolution of the Council of Ministers of the Kazakh SSR of August 26, 1987 No. 400 "On the implementation of the resolution of the Council of Ministers of the USSR of July 23, 1987 No. 841" On improving the expertise of projects and estimates for the construction of enterprises, buildings and structures, subordinate to the republican and local governments".

By the Decree of the President of the Republic of Kazakhstan of September 6, 1993, 1344 "On the New Housing Policy" on the basis of the abolished Gosarhstroy of the Republic of Kazakhstan, the Ministry of Construction, Housing and Land Development (Minstroy) of the Republic of Kazakhstan was established. The same Decree defined the structure of the Ministry of Construction, providing, in addition to the central office of the ministry, its units in regional centers and cities of republican subordination, carrying out on-site licensing, control functions, as well as state expertise of projects.

Later, as part of the ongoing administrative reform, the Government of the Republic of Kazakhstan issued Resolution No. 88 of January 24, 1996 "On Improving 
Architectural and Urban Planning in the Republic of Kazakhstan". To implement its tasks, a Republican state-owned enterprise was created on the basis of economic management "State Extradepartmental Examination of Projects" with its subsidiary state-owned enterprises in regional centers and cities of Akmola and Almaty (hereinafter referred to as RSE "Gosexpertiza").

The status of the RSE "Gosexpertiza" is additionally supported by the Law of the Republic of Kazakhstan "On State Enterprise" in which the main purpose of the activities of state enterprises is to solve social and economic problems determined by the needs of society and the state through activities in areas classified as state monopoly or States, with the exception of control and supervisory functions. The Law of the Republic of Kazakhstan "On Architectural, Urban Planning and Construction Activities in the Republic of Kazakhstan" stipulates that the state expertise of projects is a single state system, the duplication of whose functions is not allowed.

The exclusive competence of state expertise includes consideration of projects for construction:

- objects erected at the expense of budget investments and other forms of public investment;

- potentially dangerous and technically complex objects, regardless of the sources of funding;

- technical specifications for tender documentation for public procurement of contractual construction and installation works on large and complex objects.

The subject of activity of RSE "Gosexpertiza" is the state expertise of projects (pre-project and design-estimate documentation). The purpose of the RSE "Gosexpertiza" is a comprehensive assessment of urban planning projects, development and development of territories, construction of social, industrial, recreational, engineering and transport infrastructure (including power supply, water supply, heat supply, trunk transportation, communications, utilities and other life support systems).

The list of technically complex construction objects is determined in accordance with the general procedure for classifying buildings and structures as technically complex, established by the Government of the Republic of Kazakhstan. Competitive (tender) documentation for public procurement of contract work (services) for large and complex construction projects or facilities with a construction duration of more than six months is also a subject to state expertise.

In the whole of the republic, in 2014, the system of RSE "Gosexpertiza" considered 10,063 units of documentation for construction (reconstruction, major repairs, technical re-equipment). Of these, 9,888 units of documentation were recommended for approval. The analysis of the reviewed projects (work projects) for all sources of financing showed that in 2016, 8,324 units of project documentation were considered for objects funded by public investment, which is $82.7 \%$ of the total number of reviewed documentation, for private investments, invested only in 1,739 units of project documentation or $17.3 \%$.

In 2016, 106 design organizations were identified to have made numerous shortcomings and errors in the projects or projects under development, when considering which ones the State Expertise Department had to return for revision or reject them from further consideration. Due to numerous deviations from the requirements of state standards, 175 units of documentation were returned for revision. In total, the projects reviewed by experts of the RSE "Gosexpertiza" system revealed over 295,000 significant flaws and deviations from the design standards.

As a result of the adjustment of project documentation for expert comments and the exclusion of unreasonable and unearmarked costs, the total declared (estimated) estimated construction cost in 
projects for 2016 was reduced by KZT 2.06 billion USD, including projects funded by state investments -1.35 billion USD, due to the budget -0.69 billion USD.

According to the data of 2017, RSE "Gosexpertiza" (in the republic) considered 4,245 units of documentation for construction with a total stated (estimated) construction cost of 43.54 billion USD. Of these, 3,789 units with a total stated (estimated) construction cost of 40.45 billion USD were recommended for approval. As a result of the expertise, due to the poor quality of the project documentation, which is characterized by numerous flaws and violations of regulatory requirements, 456 documentation units with a total declared stated (estimated) construction cost of \$ 0.30 billion USD were returned for revision. Since 2014, 4,169 units of documentation have been returned without consideration due to the incompleteness and poor quality of the design.

As a result of the adjustment of project documentation for RSE "Gosexpertiza" comments and the application of its recommended proposals, as well as the exclusion of unreasonable and inappropriate costs, the total stated (estimated) construction costs in the projects were reduced by $\$ 3.21$ billion USD, including projects funded by public investment - 1.67 billion USD.

In connection with the ongoing revival of the construction sector in Kazakhstan, large volumes of expert work carried out by government expert organizations affect the timing and quality of the conclusions. The monopoly position of the state enterprise in the market of expert services in the field of design, holds back the pace of development of entrepreneurship in the construction and expert activities in the Republic of Kazakhstan, especially in cases when it comes to conducting a mandatory examination of projects of technically simple objects.

Examination of projects not related to the exclusive competence of state expertise is currently carried out by non-state subjects of the market of expert works (non-state experts), which now account for about $20 \%$ of the market for expertise in construction projects. The number of active non-state experts is about 150 people.

Review of foreign experience of the functioning of special institutions

For comparison, let us consider the activities of similar specialized institutions in the world practice of expert activities in the field of designing objects of architecture, construction and urban planning.

In CIS countries as a whole, the institutions of state expertise of projects for the construction of facilities have been preserved. The state expertise of projects and the state architectural and construction control over the quality of construction are entrusted to republican government bodies or other structures authorized by governments to perform relevant state functions. However, there are some organizational features of state expert activity.

In all CIS countries, the "Agreement on Interstate Examination of Projects of Mutual Interest for the Member States of the Commonwealth of Independent States" dated January 13, 1999, is based on the joint review of projects by government expert organizations.

In Russia, in contrast to Kazakhstan, the state expertise of projects is carried out by non-profit legal entities in the form of the Federal state institution and state institutions of the subjects of the Federation. Non-state experts in the field of construction and design have been officially operating since 2004, when Article 50 "Non-state examination of project documentation and non-state examination of engineering survey results" was included in the Urban Development Code of the Russian Federation, and in 2005 , the first associations of subjects of non-state examination were created. Thus, the All-Russian Public Organization "Russian Chamber of Construction Experts (Rosstroyexpertise)" was established in 
August 11, 2005 at the initiative of expert companies, which had previously been engaged in conducting non-state construction expertise, including the judicial one. According to Rostekhnadzor, as of December 2012, 179 self-regulatory organizations in the field of architectural and construction design were registered.

Until 2012, the conclusions of non-state experts did not have the same legal force as the conclusions of state experts. Changes in the Urban Development Code of the Russian Federation have equalized the legal status of the conclusion of state and non-state expertise, and have also established a new procedure for the accreditation of legal entities for the right to conduct non-state expertise of project documentation and certification of experts.

In addition to the Urban Development Code, the considered area in Russia is also regulated by the Regulation on certification for the right to prepare conclusions for expert review of project documentation and (or) engineering survey results.

An important requirement for the activities of certified experts is their lack of personal interest in the results: an expert cannot conduct an examination if he, his spouse, or close relatives participated in the preparation of project documentation and / or engineering research. This may be the basis for the revocation of the certificate, and after the cancellation, the specialist can re-submit the documents for certification only after three years.

The Civil Code of the Russian Federation defines the objects, the project documentation of which is subject to state expertise, the projects of all other objects are transferred to the competitive environment. Unlike Kazakhstan, it contains a clear list of highly dangerous, technically complex and unique objects. The powers of the state authorities of the Russian Federation in the field of urban planning include: maintaining the state register of self-regulatory organizations; implementation of state supervision over the activities of self-regulatory organizations; the establishment of an accreditation procedure for legal entities for the right to conduct non-state expertise; and maintaining the state register of the named legal entities, etc.

In most foreign countries with fairly intensive construction, state expertise of projects in conjunction with control and supervisory functions over the quality of design and construction is entrusted to special structures of state bodies (Anson et al., 2004; Clarke, 2018; Finkel, 2015; Gruneberg, 2018 Matthews et al., 2006; Morin, 2018). At the same time, control over project documentation and compliance with the draft requirements of state norms and standards, rules, technical conditions and restrictions is established at the level of legislative acts or municipal regulatory legal acts that should not conflict with national legislation.

In the United States, a public body deals with expertise, whose work is not limited to the design stage, but continues in the form of construction control, including the tolerances of deviation of structures from the design position (for example, from the vertical). Control and state examination of projects in terms of compliance with urban planning and construction legislation, compliance with the requirements of building codes and rules in force under the jurisdiction of the local government in the territory of this state or locality, is the direct responsibility of the relevant executive body (Finkel, 2015).

Examinations can be conducted by departments of a state body or a specialized state organization that has experts in all areas (sections of projects). State supervision over the quality of projects and construction is provided through a licensing mechanism, which provides for carrying out state expertise on the submitted projects, verifying the qualifications and potentials of the designers, issuing a final permit (license) for the approved project and carrying out technical supervision over the construction of this facility.

In most cases, management functions in the field of construction in the administrative 
unit are assigned to the Department of Construction, headed by the Commissioner for Construction. Each project for the construction of objects undergoes a state examination in the Department of Construction, after which the Commissioner for Construction issues a license authorizing the construction of this object.

At the same time, each specialist (and not an enterprise or organization, as in Kazakhstan), who is responsible for each section of the project, must have a personal license to produce the relevant types (subtypes) of design or exploration work, which imposes personal responsibility for the quality of their implementation.

Depending on the technical complexity of the project, experts may involve in its assessment - external experts or consulting firms with experts specializing in various areas of the project business. At the same time, the project documentation falls into the architectural department of the Department, which coordinates the work of experts in other areas, including the fire, sanitary and environmental sectors of projects under the principle of "one window".

When selecting experts to engage in state expertise, requirements for qualifications (specialization), production experience and human qualities of experts are taken into account by passing tests, including assessing knowledge of legislation and regulatory framework, manifestations of objectivity and independence of opinion, etc. At the same time, experts should not be an interested party or themselves be engaged in the design, consulting services, and other work related to the construction of facilities.

Any changes and additions to the previously approved project undergo a repeated state examination and reapproval in the Department.

To obtain a construction permit, the applicant pays the amount that includes the cost of state expertise of the project. The amount of payment depends on the amount of work, the area of the object, the number of pieces of equipment, and the hourly payment of experts involved in the analytical and evaluation work of the state expertise.

The process of state peer review and verification of the quality level of project documentation in Canada is in many ways similar to the state examination of projects in the United States. One of the main forms of work of local (at the provincial level) authorities on the analysis of design solutions and state expertise of project documentation is to hold meetings and commission discussion of projects at various stages of their development (mode of step-by-step expert support of the design process) with the participation of specially established expert consulting firms .

The head of the main department of the local executive body, who is responsible for the design of a group of objects, appoints a responsible representative of the department to participate in the commission on integrated discussion of projects. Commission members review sections of the submitted project documentation and give their opinions on them. The main purpose of creating such a commission is to conduct an analysis and then decide on the possibility of further continuation of the design work, up to and including the approval of the project and the start of its implementation.

All projects submitted to the state examination are evaluated according to established criteria on a five-point system. If one of the criteria is rated less than four points, then all project documentation is returned for revision. When being evaluated more than four, but less than five points, the project is accepted with minor notes and recommendations to take into account during the construction process. The project, which received a five-point assessment, is recommended for implementation without reservation.

In Germany, land governments are charged with the creation of relevant bodies in the structure of local executive authorities that 
oversee the planning and development of territories. These are, as a rule, land ministries or departments of construction inspection of municipalities that have specialist experts in all sections of the project business. For example, the supreme authority in building land in Bavaria is the Ministry of the Interior, which includes a construction department (building inspection authority) with its own staff, organizing the control over the design and construction, as well as the maintenance of buildings and structures.

The building inspection authorities in Germany are charged with ensuring the high quality of design and construction. To this end, projects are checked and their state expertise is carried out, at the same time, permits are issued for construction and installation works (start and construction), and inspections of facilities under construction and in operation are carried out. These organizations are staffed by professionally trained specialists who possess the necessary regulatory and engineering knowledge in the field of construction science and technology, as well as in the organization of design and survey and construction work. To perform their tasks, state building inspection authorities may involve individual experts among the highly qualified specialists included in a special registration to conduct state expert appraisal of projects.

Government experts are subject to special requirements, such as; possessing sufficient knowledge and experience in the field of design, a ban for engaging in business of construction or related fields, as well as the requirement not to be in professional, financial or any other dependent relationships, specially, with the subjects of construction activities. State experts are accountable to the Chamber and take the oath of impartiality and integrity in their professional activities. In addition, government experts may recommend to the Chamber nominations of other professionals as potential government experts.

To work with judicial, investigative or other administrative bodies, there is an institute of public experts. The decision on the appointment of experts at the public level is made by the Chamber of Architects.

Public examination is organized through a referendum, a survey of the population and discussions of individual environmental issues in municipalities.

The system and procedure for conducting state examination of projects and the supervision of construction quality in Japan are similar to the United States or Germany. The territorial principle of building a system of state control over the quality of project products and the participation of state bodies in the regulation of investment activities in these countries are also similar (Anson et al., 2004).

State expertise of projects and the quality of construction in Japan has been given an increased role and the corresponding requirements are imposed, due to the very high seismic risk throughout the country. The consequences of the Tokyo earthquake of 1927 predetermined the need to tighten the requirements for design and capital construction. All construction projects are subject to state expertise, regardless of the purpose and significance of the objects. In this regard, special services for supervision of construction and verification of projects in the territory and suburbs have been established under the municipalities of large cities. The staffing of these services depends on the volume of design and the intensity of construction in the territory under the jurisdiction of the municipality.

In a comprehensive review of construction projects, special attention is paid to the development and implementation of master plans, compliance with urban planning discipline (use of designated areas strictly for functional purposes, as defined by the master plan, requirements for red and yellow lines, environmental protection measures, etc.), optimality and safety - planning solutions for each building or structure, ensuring the structural strength and reliability of the object. 
To complete the state examination of projects by authorized bodies of management, specialized firms and consulting expert organizations are widely involved, as well as highly qualified specialists and scientists. At the same time, the principle of independence of attracted firms, organizations and experts is strictly observed, the combined methods and a comprehensive analysis of the results of state expertise are widely used.

The main functions of the central state branch body include the formation and content of the regulatory framework; organization and conduct of state examination of major investment projects and programs, as well as the development of guidelines on policy issues in design and construction.

In order to reduce the investment cycle in Japan, state expertise in the development of projects is widespread, i.e. in the mode of expert support to complete the design work. To this end, customers and project authors work with independent experts proposed by state expertise bodies at all design stages, which ensures the achievement of high quality project products by making the necessary amendments in working order for relatively short periods.

Thus, the experience of the most developed countries indicates the existence of different approaches to transfer the functions of state experts in the field of construction and urban planning to the competitive environment, caused by specific economic and political conditions.

\section{Conclusions and Recommendations}

In connection with the above, in our opinion, expert activities in Kazakhstan should be reformed, through a phased transfer from the monopoly to the competitive environment of the objects of expert activities that are now within the exclusive competence of state experts. For example, in 2020 , about $40 \%$ of projects in the field of construction and town planning (stage 1) could be submitted for consideration by non-state experts, and in
2030 - up to $80 \%$ (stage 2). The implementation of these proposals will lead to the development of a competitive environment in expert activities in the field of real estate design.

At the same time, the activities of non-state experts cannot be equated with entrepreneurial, although they are carried out in a competitive environment. The main goal of the experts' work is to establish the compliance of projects with the requirements of legislation, cityplanning and technical regulations and government regulations in order to prevent violations of property and personal nonproperty benefits and the rights of both individual subjects and the entire society and state.

At the same time, given the importance of examining projects invested at the expense of the state budget, significant in value, with unique objects, it is not advisable to completely transfer the production of examinations in the area under consideration to the competitive environment, the monopoly of the state expert organization should be retained for the production of examinations on projects of certain categories of objects.

Phased transfer of expert activities in the field of design and urban planning will require an increasing number of non-state experts, whose activities should be organized by the method of self-regulation. In particular, the system of non-state expertise will consist of non-state expert organizations, in the staff of which there must be at least three certified non-state experts in various sections of the design and estimate documentation. In the future, non-state expert organizations will also have the right to create territorial associations (at their discretion).

The subjects of non-state expert activities in some cases may also be experts individuals (for example, to conduct an examination of the estimated cost of the project), but they are in the staff of nonstate expert organizations. At the same time, each non-state expert can be a member of only one expert organization. In 
order to perform examinations that require knowledge in other areas, expert organizations are entitled to attract certified experts from organizations other than the state expert organization. The responsibility of the experts involved for the defects they have committed will be determined by the contract.

Non-state expert organizations will be given the right to consider not only the project as a whole, but also the individual parts of the project, while the state expertise, according to the law, can only take from the customer a complete set of source materials and project documents in general. At the same time, the conclusions of non-state expertise on certain parts (sections) of the project are not grounds for approving project documentation for construction, they can be used in the future only in conjunction with the examination of other parts of the project.

In order to prevent abuses and preserve objectivity during the examination, a restriction will be imposed on the examination of projects carried out by the expert's close relatives or projects in which the expert himself participated. For the same purpose, non-state expert organizations cannot be created under any other commercial legal entities, they should not be in professional, financial or other dependent relationships, primarily with the subjects of construction activities.

The powers of state and non-state experts will differ only in the types of objects of expertise: the expertise of projects of technically complex first level of responsibility and unique objects will remain under the jurisdiction of state expertise by 2025. The procedure for the examination of project (pre-project) documentation will be the same for state and non-state experts.

In order to avoid reducing the quality of examinations of construction and urban planning projects by attracting customers by non-governmental expert organizations as a result of shortening the period for conducting examinations, it is proposed to establish a minimum period for conducting examinations before which an expert opinion cannot be issued and is invalid. To this end, non-state expert organizations will be required to carefully organize the clerical work with registration of the date of receipt of documents for examination and issuance of opinions.

In connection with the development of electronic communication technologies, the experience of developed countries introduces the so-called "online expertise", that is, receiving documents for examination via remote access via the Internet, which will not only reduce customers' time, but will also increase openness and transparency of the examination and reduce corruption risks.

The transfer of expert activities in the field of designing construction projects to a competitive environment will entail the introduction of a new regulatory procedure in the field of non-governmental expert activities, which results in the need to review the punishment, which should be commensurate with the degree of expert guilt and be preventive.

The implementation of the recommended changes will help create favorable conditions for improving the quality of design, developing the market for expert services by transferring up to $90 \%$ of the work on project expertise to a competitive environment, as well as institutional and quality strengthening of expert activities. For the population and business entities, the adoption of the bill will entail the realization of the right to use high-quality real estate objects.

The state budget will be replenished by paying taxes by non-state expert organizations. Positive consequences will also be expressed in reducing the burden on state expert organizations. Social consequences are also in the creation of many new jobs in the form of engaging in activities as non-state construction experts. In return, the effectiveness of project expertise will increase, as well as additional guarantees of the quality of expert activities, in connection with the 
establishment of increased legal liability of experts.

\section{References}

1. Agreement on interstate examination of construction projects of mutual interest to the States members of the Commonwealth of Independent States (Saratov, January 13, 1999). 1999. Available: https://online.zakon.kz/Document/?doc id $=1017569$ \#pos $=0 ; 0$

2. Anson, M., Chiang, Y.H. and Raftery J. (2004), 'The Construction Sector in the Asian Economies '. Published by Routledge.

3. Business Climate 2016. Available: http://atameken.kz/ru/projects/category/ delovoj-klimat

4. Boronenko, V. and Lavrinenko, 0. (2015), 'Territorial development of Iceland: case study of social and economic interactions within global context '. Social sciences for regional development in 2015: Proceedings of the $\mathrm{X}$ International scientific. Conf. (16-17 October 2015). Daugavpils University Latvia.

5. Clarke, W. (2018), 'Institutional density reconsidered: States, international organisations, and the governance space', Journal of International Relations and Development. Available: https://link.springer.com/article/10.1057 \%2Fs41268-017-0113-1

6. Dobrovolskienè, N., Tvaronavičienė, M., and Tamošiūnienè, R. (2017), 'Tackling projects on sustainability: a Lithuanian case study ', Entrepreneurship and Sustainability Issues 4(4), 477-488, https://doi.org/10.9770/jesi.2017.4.4(6).

7. Finkel, G. (2015), 'The Economics of the Construction Industry Routledge '. Published by Routledge

8. Gruneberg, S. (2018), 'A Strategic Approach to the UK Construction Industry '. Published by Routledge.
9. Ignatavičius, R., Tvaronavičienè, M. and Piccinetti, L. (2015), 'Sustainable development through technology transfer networks: case of Lithuania ', Journal of Security and Sustainability Issues 4(3): 261267.

DOI: http://dx.doi.org/10.9770/jssi.2015.4.3(6)

10. Kapitonov I., Taspenova G., Meshkov V. and Shulus A. (2017), 'Integration of small and middle-sized enterprises into large energy corporations as a factor of business sustainability ', International Journal of Energy Economics and Policy 7(2). Available: https://www.econjournals.com/index.php Lijeep/article/view/4040

11. Law of the Republic of Kazakhstan dated July 16, 2001 No. 242-II "On the architectural, urban planning and construction activities in the Republic of Kazakhstan" (with amendments and additions as of December 28, 2018). Available:

https://online.zakon.kz/Document/?doc id $\underline{=1024035}$

12. Mavlyanova, N., Denisov, I. and Lipatov, V. (2015), 'Environmental problem analyses for cross-border territories of former soviet union countries ', Environmental Protection and Sustainable Ecological Development. DOI: https://doi.org/10.1201/b18507

13. Matthews, D. and Munoz-Tellez, V. (2006), 'Bilateral technical assistance and TRIPS: The United States, Japan and the European communities in comparative perspective ', Journal of World Intellectual Property, 9(6). DOI: https://doi.org/10.1111/j.1422$\underline{2213.2006 .00305 . x}$

14. Morin, J.-F. (2018), 'Concentration Despite Competition: The Organizational Ecology of Technical Assistance Providers', Review of International Organizations Available:

https://link.springer.com/article/10.1007 Ls11558-018-9322-7

15. National report on the state of entrepreneurial activity in the Republic of 
Kazakhstan.

Available:

http://atameken.kz/uploads/content/files L\%D0\%A2\%D0\%B5\%D0\%BA\%D1\%81\%

$\underline{\mathrm{D} 1}$

16. Nikitina, M., Pobirchenko, V., Shutaieva, E. and Karlova, A. (2018), 'The investment component in a nation's economic security: the case of the Russian Federation ', Entrepreneurship and Sustainability Issues 6(2): 958-967. DOI: http://doi.org/10.9770/jesi.2018.6.2(32)

17. North D. (1997), Institutions, institutional change and the functioning of the economy. M.: Foundation of the economic book "Beginning". Available: http://www.schumpeter.ru/content/Nortinstitutes.pdf

18. Official Internet-resource of Committee of Statistics of Ministry of the national economy of the Republic of Kazakhstan. Available: www.stat.gov.kz

19. Olefirenko, O., Petrenko, E., Shevyakova, A. and Zhartay, Z. (2016), 'Towards economic security through diversification: case of Kazakhstan', Entrepreneurship and Sustainability Issues, 5(4): 509-518. DOI: http://dx.doi.org/10.9770/jssi.2016.5.4(6)

20. Petrenko E., Iskakov N., Metsyk O. and Khassanova T. (2017), 'Ecosystem of entrepreneurship: risks related to loss of trust in stability of economic environment in Kazakhstan ', Entrepreneurship and Sustainability Issues 5(1): 105-115. DOI: https://doi.org/10.9770/jesi.2017.5.1(8)

21. Shevyakova A., Tyugina I., Arystan M. and Munsh E. 2018. 'Transformation of economy towards tourism: case of Kazakhstan ', Entrepreneurship and Sustainability Issues 7(3): 603-618. DOI: http://doi.org/10.9770/jssi.2018.7.3(19)

22. Strielkowski, W., Lisin, E. and Tvaronavičienè, M. (2016), 'Towards energy security: sustainable development of electrical energy storage ', Journal of Security and Sustainability Issues 6(2): 4352.

DOI:
23. The Global Competitiveness Report 2015-2016 and 2017-20 World Economic Forum, 2015 and 2018. Retrieved from http://reports.weforum.org

24. Uraev N., Mingaleev G., Kushimov A. and Kolesov N. (2016.), 'Methodological aspects of strategic development of regional socio-economic system (following the example of radio-electronic industry enterprises in the Republic of Tatarstan) ', International Journal of Environmental and Science Education. 11(12). ijese.2016.378: 5094-5108.

http://www.ijese.net/makale/690

25. Urban Development Code of the Russian Federation (as amended on August 3 , 2018) (revised from January 1, 2019) DOI: http://www.gradkod.ru/

26. World Bank. (2015). Kazakhstan: Adjusting to Low Oil Prices, Challenging Times Ahead. Available: http://www.worldbank.org/en/country/k azakhstan/publication/economic-updatefall-20152

27. World Bank Report. (2012). Critical look at 30 years of preparing world development reports. http://documents.vsemirnyjbank.org/cura ted/ru/2012/10/18575898/developmenteconomics-through-decades-critical-look30-years-world-development-report

http://atameken.kz/

https://strategy2050.kz/

\section{Anna Shevyakova}

ORCID ID: orcid.org/0000-0002-2644$\underline{6292}$

Yelena Petrenko

ORCID ID: orcid.org/0000-0001-6892$\underline{2392}$

Malika Arystan

ORCID ID: orcid.org/0000-0003-4921$\underline{6577}$

Gaukhar Koshebayeva

ORCID ID: orcid.org/0000-0002-0393$\underline{9844}$. 